\title{
Inter-Firm Trust Production: Theoretical Perspectives
}

\author{
Nguyen Phuc Nguyen ${ }^{1} \&$ Nguyen Thanh Liem ${ }^{2}$ \\ ${ }^{1}$ University of Economics, The University of Da Nang, Vietnam \\ ${ }^{2}$ Department of Business Administration, University of Economics, Vietnam \\ Correspondence: Nguyen Phuc Nguyen, University of Economics, The University of Da Nang, Da Nang 5113, \\ 71 Ngu Hanh Son, Da Nang, Vietnam. Tel: 84-511-383-6934. E-mail: nguyennp@ud.edu.vn
}

Received: December 31, 2012

Accepted: January 29, 2013

Online Published: March 14, 2013

doi:10.5539/ijbm.v8n7p46

URL: http://dx.doi.org/10.5539/ijbm.v8n7p46

\begin{abstract}
Although inter-firm trust plays a crucial role in inter-firm relationships that involve uncertainty, limited research has devoted to make a full review on inter-firm trust. The objective of the study is to investigate the sources of inter-firm trust in order to give a basement for building inter-firm trust. Drawn from many disciplines such as relationship marketing, social exchange theory, management, etc., this study has built the conceptual model to facilitate trust between partners in inter-firm relationships intentionally. The paper contributes to the knowledge of inter-firm relationships based on viewing trust from many perspectives. The paper also proposes some hypotheses related to inter-firm trust development which will be checked by future research.
\end{abstract}

Keywords: trust, communication, attributes, institutions, social network

\section{Introduction}

Building and developing long-term and mutually beneficial relationships with partners have emerged as a central topic in the area of inter-firm relationship; even in the firms that possess necessary resources to consider running business independently (Fang et al., 2008). Companies establish inter-firm cooperation with others due to various reasons including learning new knowledge or skills (Hanna \& Walsh, 2008), reducing costs (Cannon \& Homburg, 2001), seeking external resources (Miotti \& Sachwald, 2003), or enhancing firm's performance (Rosenfeld, 1996; Zollo et al., 2002). Many empirical studies have confirmed that inter-firm cooperation becomes an important strategy in helping firms to deal with changes in customer needs or to achieve success in global marketplace. As a result, finding the way to foster this relationship is a key element in maintaining and developing firms' competitive advantage.

On the other hand, we have experienced the failure of many alliances over time (e.g. Bamford et al., 2004; Pak et al., 2009). As a result, understanding the factors related to success of inter-firm relations has become an important subject of investigation. Among these important factors, a lack of trust is an often-cited reason for why business relationship fails to develop and leads to the ultimate dissolution of inter-firm cooperation (Buchel, 2003). Moreover, although inter-firm cooperation can be achieved through diverse mechanisms, scholars working in the field of business relationship have highlighted the importance of trust as a means of establishing and sustaining this relationship (Anderson \& Narus, 1990; Lancastre \& Lages, 2006; Lui et al., 2006; Morgan \& Hunt, 1994). This would come to the necessary of studying inter-firm trust. Trust, therefore, has been studied in various disciplines such as psychology (Rotter, 1967), social theory (Zucker, 1986) or marketing and management (e.g. Morgan \& Hunt, 1994; Zaheer et al., 1998). In addition, many studies have been devoted to examine the nature of inter-firm trust (e.g. Anderson \& Narus, 1990; Fang et al., 2008; Kennedy et al., 2001; Morgan \& Hunt, 1994; Zaheer et al., 1998).

In spite of the importance of trust and increased interests among researchers as well as managers, there is not a research to make a full review on inter-firm trust. Moreover, although inter-firm trust can be engendered from organization, company's representatives or circumstances, most of the focuses are at one or both targets, not all (e.g. Doney \& Canon, 1997; Kennedy et al., 2001; Moorman et al., 1993; Nguyen \& Rose, 2009). Thus, examining the foundation of trust is the main research question of this paper. The study, therefore, attempts to advance theory of inter-firm relations by investigating the basement of trust as well as factors that affect trust building between partners. More specifically, we examine the characteristics of inter-firm trust in order to give the broad definition of trust. We use an interdisciplinary approach to examine inter-firm trust because the 
concept seems to be somewhat different, depending on the circumstances, based on which we form the model of inter-firm trust as the result.

The rest of the paper is organized as follows. To begin with, the trust concept and its characteristics are presented, along with the proposed definition of trust in general. The following part contains a detailed description of the levels of trust. After presenting the model of inter-firm trust based on its foundations, some hypotheses will be presented as the open-gate for future research. The paper concludes some managerial implications.

\section{Trust Concept and Definitions}

There are a number of definitions of trust from various disciplines. In psychology, Rotter (1967) says that trust is an expectation held by an individual or a group that the word, promise, verbal or written statement of another individual or group can be relied upon. In sociality theory, trust is a bet about the future contingent actions of other (Sztompka, 2003) or is a set of expectations shared by all those involved in an exchange (Zucker, 1986). While studies of trust have their roots in psychology and social psychology with the common share that interpersonal trust resides within individuals, it has been used and been extended into organizational level by marketing and management scholars. For instance, Anderson and Narus (1990) define trust as the firm's belief that another company will perform activities resulting in positive outcomes for the firm, as well as not take unexpected actions that would result in negative outcomes for the company. Similarly, trust can be viewed as one party's confidence that the other party in the exchange relations will not exploit its vulnerabilities (Dyer \& Chu, 2000). Furthermore, trust has been studied from personal level like interpersonal trust in McAllister (1995), and salesperson trust in Plank et al. (1999) or organizational level such as company trust (Mayer et al., 1995). Most academicians define trust in general way, irrespective of level of trust (e.g. Anderson \& Narus, 1990; Bhattacharya et al., 1998; Doney \& Cannon, 1997; Rousseau et al., 1998). Consequently, what does inter-firm trust mean? To answer this question, we firstly take a look at characteristics of trust.

\subsection{Characteristics of Trust}

Based on definitions of trust and literature review, we can infer four characteristics of trust as follows:

\subsubsection{Trust Is Risk}

Trust associates with risk and it is a remedy for specific problem of risk. Without uncertainty environment or risk, trust has no meaning (Bhattacharya et al., 1998). Because the results do not have any consequences for the trustor (Rodríguez et al., 2007). In the context of inter-organizational relationships, opportunism always exists in which one partner can take advantage from the others (Cumming \& Bromiley, 1996). Trusting somebody or something, therefore, means that we travel with risk for betting about uncertain future (Curral \& Inkpen, 2002; Nooteboom, 2002; Sztompka, 2003; Zaheer et al., 1998).

\subsubsection{Trust Relates to Vulnerability}

Trust is a context-based concept. Because of risky environment where trust is located, the actor experiences a vulnerable situation. Basing on the confidence in another partner's words or written statement, the partner just expects that the other will not take chances even if there is an incentive for it (Dyer \& Chu 2000; Sako \& Helper, 1998; Wilson et al., 2006). Moreover, we trust somebody means that we depend on them. As a result, we are in a vulnerable position (McKnight et al., 1998).

\subsubsection{Trust Relates to Expectation}

There is an actor's expectation of another who will do favored things in creating the positive (or nonnegative) results. The trusting person is thought to expect the best from ongoing relations (Hosmer, 1995). The expectation is based on the credibility of other party's competency or expertise in fulfilling his/her obligation. From other party's point of view, the expectation requires benevolence from the current party who will care about other's welfare or act in the alliance's best interest (Edelenbos \& Klijn, 2007; Ganesan \& Hess, 1997; Rousseau et al., 1998; Seppänen et al., 2007 and Zaheer et al., 1998). Based on this expectation, company will formulate relations with other companies.

\subsubsection{Trust Is Confidence}

Trust is the confidence that a firm's partner will not act opportunistically and will not exploit firm's vulnerability (Kwon \& Suh, 2005; Mayer et al., 1995; Sako, 1992). The confidence includes the belief that firm's partner will perform in predicted manner. In addition, a partner is confident that its expectations will not be disappointed.

Therefore, we can define trust as the expectation held by a party toward another party or objects that the trustee 
will behave in a predictable manner, not exploit the other's vulnerability in case of opportunism. This definition reflects all characteristics of trust and can be used not only for interpersonal trust but also for inter-organizational trust. It also mentions the context where trust can take place. Furthermore, we view trust as an output rather than a cause (Zucker, 1986). By this way, a company or its representatives can build inter-firm trust intentionally.

\subsection{Levels of Trust}

The extensive literature on trust derives from various disciplines (e.g. Rousseau et al., 1998; Seppänen et al., 2007). For specific purpose and context of the studies, academicians have investigated trust in different views. If they study trust in general, irrespective to the target of trust, they define it as general trust (Bhattacharya et al., 1998; Mayer et al., 1995; Rodríguez et al., 2007; Rousseau et al., 1998). On the other hand, if they want to investigate the impact of trust on subjects related to specific relations, they classify trust as inter-firm trust (e.g. Anderson \& Narus, 1990; Nguyen et al., 2005; Plank et al., 1999), group trust (Currall \& Inkpen, 2002), agency trust (Fang et al., 2008), and interpersonal trust (e.g. Currall \& Inkpen, 2002; Doney \& Cannon, 1997; Gassenheimer \& Manolis, 2001; Nguyen \& Rose, 2009). Although the variety of types of trust level indicates that trust is complex and has multiple dimensions, based on authors' knowledge, there are three levels of trust in common: upper level, medium level and lower level.

We can figure the levels of trust in following diagram.

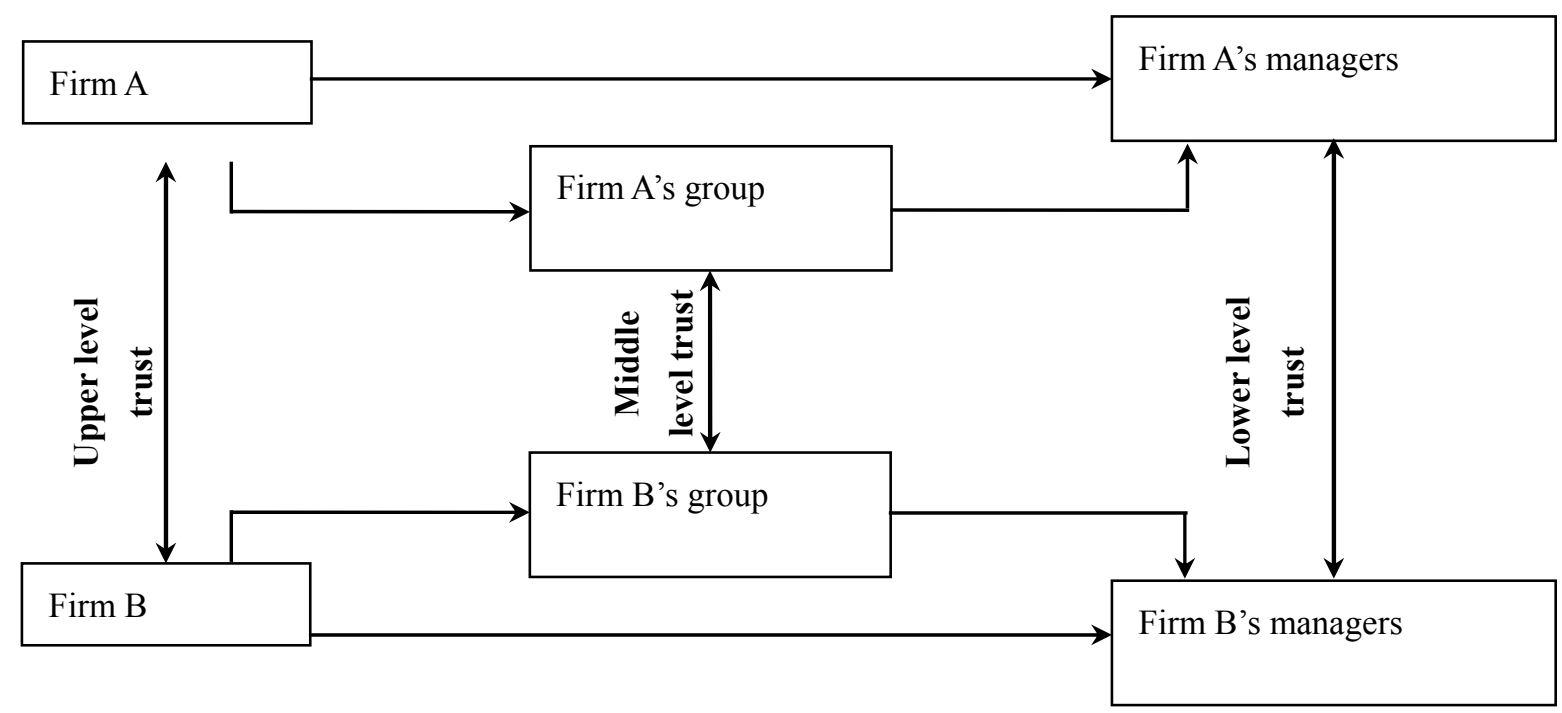

Figure 1. Levels of trust in inter-firm relationship

- Upper level trust: (inter-organizational trust). This is trust between firms or organizations in mutual relationships. This shows trust in the highest level. Many studies focus on this type of trust such as Bonte (2008); Costa e Silva et al., (2012); Seppänen et al., (2007).

- Middle level trust: (known as intergroup trust) refers to trust between groups or departments assigned to the inter-firm relationships. In some cases, a parent company assigns a particular person for specific relationship with its partner. This reflects the level of firm's agency trust in its representatives (defined as agency trust in Fang et al., 2008). However, the study will not investigate the impact of agency trust because the authors thinks that the parent company or firm assigns particular group or agency to particular inter-firm relationship only if it trusts that representatives.

- Lower level trust: (interpersonal trust) refers to trust between representatives of collaborating organizations. Individual manager, on behalf of the organization, often engages in behaviours with partner's manager, including trusting (Adobor, 2005; Zaheer et al., 1998).

\section{Framework for Trust Development}

The study of trust may be categorized according to how trust is viewed. If we look at subjects related to trust, trust is viewed from different levels as mentioned above. On the other hand, if we investigate the origins where trust is formed or process by which trust is affected, there are many forms of trust. For instance, Zucker (1986) 
proposes three forms of trust: process-based trust, characteristics-based trust and institutional-based trust. Shapiro et al. (1992) came up with a three-way classification of trust from economics: deterrence-based trust, knowledge-based trust and identification-based trust. All forms of trust have been summarized in Table 1 (which is extracted from Dwivedi et al., 2003 with supplementary).

Table 1. Sources and forms of trust

\begin{tabular}{|c|c|c|c|}
\hline Forms of trust & Foundation & Disciplines & Description \\
\hline $\begin{array}{l}\text { Characteristic based } \\
\text { trust }\end{array}$ & $\begin{array}{l}\text { Tied to person on } \\
\text { characteristics, social } \\
\text { similarity. }\end{array}$ & Sociology, Zucker (1986) & $\begin{array}{l}\text { It provides background to develop mutual } \\
\text { understanding. }\end{array}$ \\
\hline $\begin{array}{l}\text { Process-based } \\
\text { trust }\end{array}$ & $\begin{array}{l}\text { Tied to past or expected } \\
\text { exchange }\end{array}$ & Sociology, Zucker (1986) & $\begin{array}{l}\text { Develop based on past or repeat exchange among } \\
\text { partners }\end{array}$ \\
\hline Institution-based trust & $\begin{array}{l}\text { Tied to formal social } \\
\text { structure, broader society } \\
\text { institutions }\end{array}$ & $\begin{array}{l}\text { Sociology: Zucker (1986), } \\
\text { Managemnent: Rousseau } \\
\text { et al. (1998) }\end{array}$ & $\begin{array}{l}\text { Person or firm-specific attributes or intermediary } \\
\text { mechanism shapes the condition for trust to arise. }\end{array}$ \\
\hline Deterrence based trust & Fear of consequences & $\begin{array}{l}\text { Economics: Shapiro et al. } \\
\text { (1992) } \\
\text { Management: Rousseau et } \\
\text { al. (1998) }\end{array}$ & $\begin{array}{l}\text { Consistency of behavior constrained by the } \\
\text { potential costs of discontinuing the relationship }\end{array}$ \\
\hline $\begin{array}{l}\text { Knowledge-based } \\
\text { trust }\end{array}$ & $\begin{array}{l}\text { Understand the other } \\
\text { sufficiently well }\end{array}$ & $\begin{array}{l}\text { Economics, Shapiro et al. } \\
\text { (1992) }\end{array}$ & $\begin{array}{l}\text { Predict other behavior based on history of } \\
\text { relationship }\end{array}$ \\
\hline $\begin{array}{l}\text { Identification } \\
\text {-based trust }\end{array}$ & $\begin{array}{l}\text { One party has fully } \\
\text { internalized the other's } \\
\text { preferences. }\end{array}$ & $\begin{array}{l}\text { Economics, Shapiro et al. } \\
\text { (1992) }\end{array}$ & $\begin{array}{l}\text { Understanding others' want. This is the highest } \\
\text { level of trust. }\end{array}$ \\
\hline Contractual trust & $\begin{array}{l}\text { Tied to specific written or } \\
\text { oral arrangement }\end{array}$ & Management, Sako (1992) & $\begin{array}{l}\text { Promises to be kept based on agreed rules and trust } \\
\text { will be developed by contact. }\end{array}$ \\
\hline Competence trust & $\begin{array}{l}\text { Based on partner's } \\
\text { competency }\end{array}$ & Management, Sako (1992) & $\begin{array}{l}\text { An actor predicts other's ability and expectation } \\
\text { he/she will perform role competently. }\end{array}$ \\
\hline Goodwill trust & $\begin{array}{l}\text { Mutual expectation and } \\
\text { commitment }\end{array}$ & Management, Sako (1992) & $\begin{array}{l}\text { No explicit promises, vulnerability in taking } \\
\text { initiatives for other. }\end{array}$ \\
\hline Calculus-based trust & Based on rational choice & $\begin{array}{l}\text { Managemnent, Rousseau } \\
\text { et al. (1998) }\end{array}$ & The perception of benefit from the relationship \\
\hline Relational trust & $\begin{array}{l}\text { Tied to } \\
\text { interaction }\end{array}$ & $\begin{array}{l}\text { Managemnent, Rousseau } \\
\text { et al. (1998) }\end{array}$ & $\begin{array}{l}\text { From repeated interaction, parties obtain } \\
\text { information and experience for the basis of trust. }\end{array}$ \\
\hline
\end{tabular}

Although authors have classified trust into different kinds, all of them have the similarity in sources and process. For the authors' knowledge, there are two ways for classifying trust based on the origins where trust is born or on the process on which trust will be developed.

\subsection{The Origin of Trust}

The origin of trust will answer the question where trust can be born. From the literature, there are three sources of trust (from attributes or competency of objects, social structure, and formal institutions).

\subsubsection{From Attributes or Competency of Objects}

In this basement, trust can be tied to objects based on its competency or characteristics. As discussed earlier, subjects in inter-firm relationships include firms, its group, and its representative managers. From this base, trust is named as characteristic based trust (Zucker, 1986) or competence trust (Sako, 1992). According to Mayer et al. (1995), factor affecting trust that one firm places on another is traits of the trustor. It includes set of skills, competences, and characteristics that enable a firm to influence on other firms within a specific area. In the effort of validating the model of Mayer et al. (1995), Gill et al. (2005) discover that participants trust the co-worker more when the co-worker has high proficiency and benevolence. Similarly, salesperson's competence and selling tactics are proposed to create a perception of buyer trust (Kennedy et al., 2001). The organizational characteristics are thought to have a direct influence on trust (inter-organizational trust and interpersonal trust). On the other hand, Moorman et al. (1993) find that expertise of market researcher positively influences trust by the user. Further, in their empirical analysis, Doney and Canon (1997) find the positive impact of buyer as well 
as seller characteristics such as reputation, size, and expertise on trust. Recently, Wang and Gordon (2011) argue that at micro level, demographic characteristics of individuals shape trust intention. In general, these attributes will form trust in the initial stage of interpersonal or inter-organizational relationship because initial trust between parties will not be based on any kind of previous experience or firsthand knowledge of other parties (McKnight et al., 1998, p.474).

\subsubsection{From Social Structure}

Trust will be shaped by the role of third party like institutions, intermediate parties. It is named as institution based trust (Zucker, 1986) or contractual trust and goodwill trust (Sako, 1992). Social structure includes formal institutions and informal institutions (social network). Taking into account micro-unit and macro-unit level of analyzing the nature of contextual effects, Wang and Gordon (2011) report that formal and informal institutions shape degrees of trust.

- Formal institutions. Formal institutions involve laws, regulations, and political systems. Lane and Bachmanm (1997) conclude that producing trust requires strong and consistent institutions. Further, institutional environment will shape business relations. Formal institutions support the monitoring and sanctioning of social behavior (Zaheer \& Zaheer, 2006). On the one hand, they help to prevent opportunistic behavior by formal contract or asset specificity and foster trust latterly (Ganesan, 1994; Lui et al., 2009). Morever, companies can use formal institutions as the way to direct parties toward acceptable behavior and to prevent opportunism. They play a role as guides for current contracts with partner (Nguyen $\&$ Rose, 2009). Further, managers should use contracts, sanctioning capabilities, or legalistic procedures as formal substitutes for interpersonal trust (Sitkin \& Roth, 1993).

- Informal institutions (social network). Trust can also be transitive among members of a social network (Coleman, 1988). In their study of Japanese supplier network, Hagen and Choe (1998) find that social sanctions embedded in Japan prevent the participants from falling prey to the prisoner's dilemma and foster them to support inter-firm trust as an important business norm. On the other hand, social network provides same set of rules for its member. Therefore, these rules, as the role of social sanctions, prevent partners from engaging in opportunistic behavior. Social network also provides opportunities for firm to learn about new partners (Nguyen \& Rose, 2009).

\subsection{The Process by Which Trust will be Developed}

\subsubsection{From Relationship History}

In this foundation, the history or outcomes of past relationship with objects will formulate trust. Trust is called as process-based trust (Zucker, 1986), knowledge-based trust (Shapiro et al., 1992) and relational trust (Rousseau et al., 1998). The firm can develop trust with its partner by learning actively about that partner. To demonstrate and to learn about other's ability and integrity, communication between partners is a crucial way (Nguyen et al., 2005). Communication helps partners in solving disputes and aligning perception (Aulakh et al., 1996). Communication has been proven to have a positive effect on trust (Anderson and Narus, 1990). Further, according to Nguyen and Rose (2009), managers can actively develop trust between partners through two different strategies: establishing personal rapport with representatives of the partner and sharing business information and practices. All of them emphasize the importance and the need of communication in the effort of developing inter-firm trust among partners.

\subsubsection{From the Expectation on Forthcoming Relationship}

From economic point of view, authors have classified trust based on expected benefit. It is named as deterrence based trust (Shapiro et al., 1992) or calculus based trust (Rousseau et al., 1998). In this base, trust will be formed based on the consideration of benefits and costs related to inter-firm relationships. Moreover, satisfaction from previous relations will enhance trust degree between partners (Ganesan, 1994; Kwon \& Suh, 2004). However, this type of trust cannot be engendered for new relationship. Furthermore, some authors have raised the issue that deterrence based trust is not trust at all (Sitkin \& Roth, 1993). Consequently, the study will not take this trust into account.

\subsubsection{From Geographical Proximity}

Unlike social structure, this element creates a chance for communicating among partners. According to Bonte (2008), firms find it easier to touch and manage the relations with a geographically proximate partner rather than distant one. Firms located in local network will know each other. Thus, both vertical integration and horizontal integration will be easier (Nguyen, 2011). Based on that, trust production will be facilitated. We can see these foundations of inter-firm trust in the following diagram (Figure 2). 


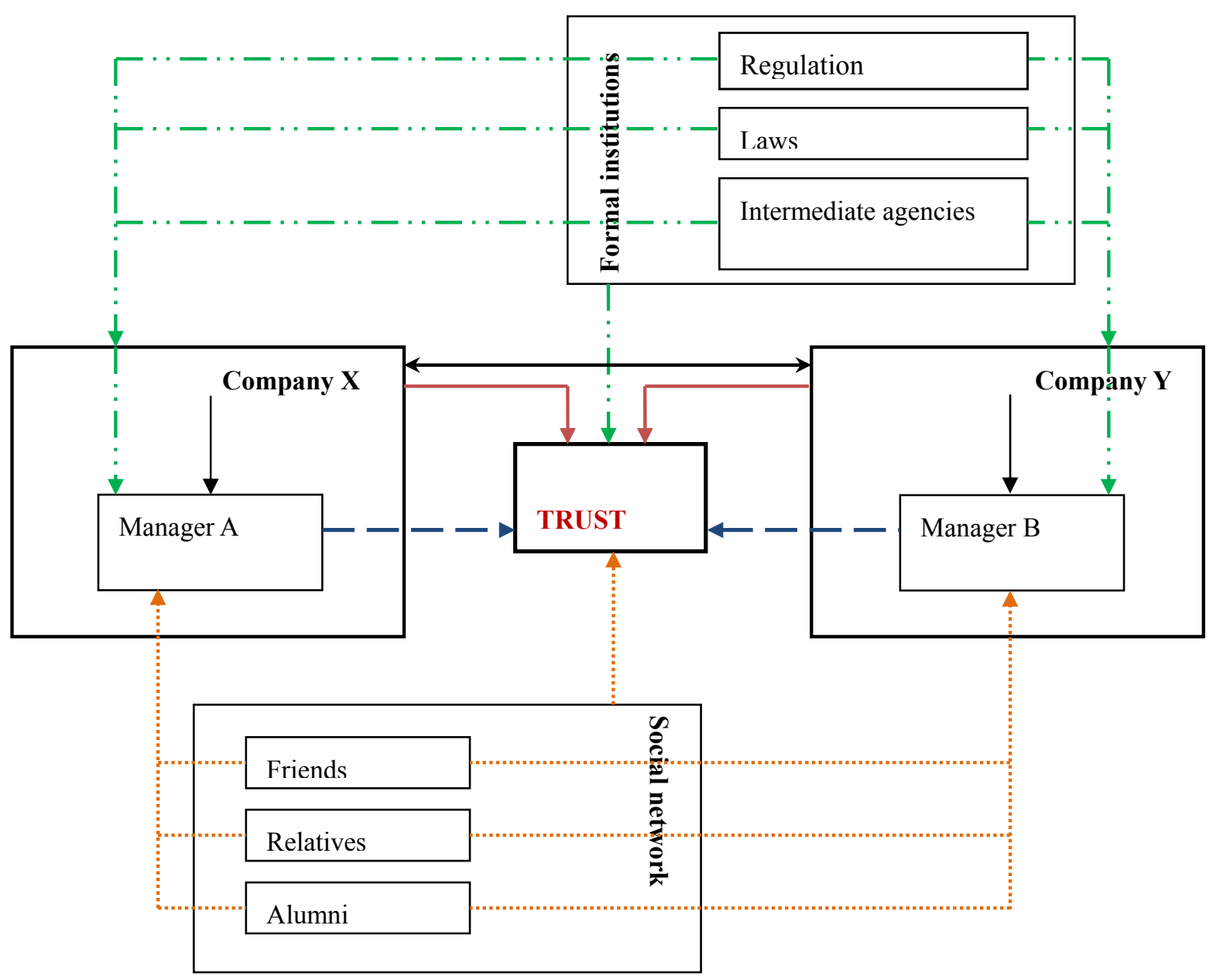

Figure 2. The framework of inter-firm trust production

Note: $\cdots \cdots \cdots \cdots$ The influence of social network on trust and its related objects
$\longrightarrow$ The influence of managers on trust
$\longrightarrow$ The influence of company on trust
$-\cdots \rightarrow$ The influence of formal institutions on trust and its related objects
$\longleftrightarrow$ Geographically proximity effect

\section{Proposed Hypotheses}

Based on the above discussion, we can conclude that trust between partners will be influenced by attributes of partner itself as well as the mechanism where trust can be fostered. By that, we infer these attributes (including company and its managers' attributes) as the fixed-side of inter-firm trust. The other (institutional environment) plays a role of the soft- side of trust. Therefore, we can propose that:

- Proposition. Inter-firm trust will be a function of the attributes and institutional environment.

- Hypothesis 1. There is a positive relationship between inter-firm trust and company as well as managers' attributes.

- Hypothesis 2. There is a positive relationship between inter-firm trust and institutions.

- Hypothesis 3. There is a positive relationship between inter-firm trust and geographically proximity.

\section{Conclusions}

This study examines the characteristics of inter-firm trust and its foundation. Based on investigating 54 articles and 3 books related to trust and inter-firm trust, four characteristics of trust are discovered. This paper contributes to knowledge of inter-firm trust. This may be the first research which investigates inter-firm trust from multi-disciplines. The framework of inter-firm trust proposed in this paper will enhance our knowledge 
about trust. Therefore, all previous research related to trust were combined to become unity. This study also provides some interesting insights for managers. The managers can build inter-firm trust intentionally through applied mechanism. It can stem from attributes of its representatives as well as itself or from social network where its representatives locate. Beyond attributes related to attributes of network, the geographical proximity will be expected to affect trust production between partners.

The study also shows its limitations. Because its concentration relates to theoretical perspective, empirical evidence should be shown in future research to prove the proposed framework. Moreover, further work should test the levels of trust in different geographical or industrial contexts to provide the more foundation of the relationships between these levels.

\section{References}

Adobor, H. (2005). Trust as sense making: The micro dynamics of trust in inter firm alliances. Journal of Business Research, 58(3), 330-337. http://dx.doi.org/10.1016/S0148-2963(03)00077-8

Anderson, J. C., \& Narus, J. A. (1990). Model of distributor firm and manufacturer firm working partnerships. Journal of Marketing, 54(1), 42-58.

Aulakh, P. S., Kotabe, M., \& Sahay, A. (1996). Trust and performance in cross-border marketing partnerships: A behavioral approach. Journal of International Business Studies, 27(5), 1005-1032. http://dx.doi.org/10.1057/palgrave.jibs.8490161

Bamford, J., Ernst, D., \& Gubini, D. G. (2004). Launching a world-class joint venture. Harvard Business Review, 82(2), 91-100.

Bhattacharya, R., Devinney, T. M., \& Pillutla, M. M. (1998). A formal model of trust based on outcomes. Academy of Management Review, 23(3), 459-472. http://dx.doi.org/10.2307/259289

Bonte, W. (2008). Inter-firm trust in buyer-supplier relations: Are knowledge spillovers and geographical proximity relevant? Journal of Economic Behavior \& Organization, 67(3-4), 855-870. http://dx.doi.org/10.1016/j.jebo.2006.12.004

Buchel, B. (2003). Managing partner relationships in joint ventures. MIT Sloan Management Review, 44(4), 91-95.

Cannon, J. P., \& Homburg, C. (2001). Buyer-supplier relationships and customer firm costs. Journal of Marketing, 65(1), 29-43. http://dx.doi.org/10.1509/jmkg.65.1.29.18136

Coleman, J. S. (1988). Social capital in the creation of human capital. The American Journal of Sociology, 94, S95-S120. http://dx.doi.org/10.2307/2780243

Costa e Silva, S., Bradley, F., \& Sousa, C. M. P. (2012). Empirical test of the trust-performance link in an international alliances. International Business Review, 21(2), 293-306. http://dx.doi.org/10.1016/j.ibusrev.2011.03.006

Curral, S. C., \& Inkpen, A. C. (2002). A multilevel approach to trust in joint ventures. Journal of International Business Studies, 33(3), 479-495. http://dx.doi.org/10.1057/palgrave.jibs.8491027

Doney, P. M., \& Cannon, J. P. (1997). An examination of the nature of trust in buy-seller relationships. Journal of Marketing, 61(2), 35-51. http://dx.doi.org/10.2307/1251829

Dwivedi, M., Varman, R., \& Saxena, K. K. (2003). Nature of trust in small firm clusters. International Journal of Organizational Analysis, 11(2), 93-103. http://dx.doi.org/10.1108/eb028964

Dyer, J. H., \& Chu, W. (2000). The determinants of trust in supplier-automaker relationships in the United States, Japan and Korea. Journal of International Business Studies, 31(2), 259-285. http://dx.doi.org/10.1057/palgrave.jibs.8490905

Edelenbos, J., \& Klijn, E. H. (2007). Trust in complex decision-making networks: A theoretical and empirical exploration. Administration and Society, 39(1), 25-50. http://dx.doi.org/10.1177/0095399706294460

Fang, E., Palmatier, R. W., Scheer, L. K., \& Li, N. (2008). Trust at different organizational levels. Journal of Marketing, 72(2), 80-98. http://dx.doi.org/10.1509/jmkg.72.2.80

Ganesan, S. (1994). Determinants of long-term orientation in buyer-seller relationships. Journal of Marketing, 58(2), 1-19.

Ganesan, S., \& Hess, R. (1997). Dimensions and levels of trust: Implications for commitment to a relationship. Marketing Letters, 8(4), 439-448. http://dx.doi.org/10.1023/A:1007955514781 
Gassenheimer, J. B., \& Manolis, C. (2001). The influence of product customization and supplier selection on future intentions: The mediating effects of salesperson and organizational trust. Journal of Management Issues, 13(4), 418-435.

Hagen, J. M., \& Choe, S. (1998). Trust in Japanese inter firm relations: Institutional sanctions matter. Academy of Management Review, 23(3), 589-600. http://dx.doi.org/10.5465/AMR.1998.926628

Hanna, V., \& Walsh, K. (2008). Inter firm cooperation among small manufacturing firms. International Small Business Journal, 26(3), 299-321. http://dx.doi.org/10.1177/0266242608088740

Hosmer, L. T. (1995). Trust: The connecting link between organizational theory and philosophical ethics. Academy of Management Review, 20(2), 379-403. http://dx.doi.org/10.2307/258851

Kennedy, M. S., Ferrell, L. K., \& LeClairb, D. T. (2001). Consumers' trust of salesperson and manufacturer: An $\begin{array}{lllll}\text { empirical study. Journal of Business Research, } & \text { 51(1), }\end{array}$ http://dx.doi.org/10.1016/S0148-2963(99)00039-9

Kwon, Ik-W., \& Suh, T. (2004). Factors affecting the level of trust and commitment in supply chain relationships. Journal of Supply Chain Management, 40(2), 4-14. http://dx.doi.org/10.1111/j.1745-493X.2004.tb00165.x.

Kwon, Ik-W., \& Suh, T. (2005). Trust, commitment and relationships in supply chain management: A path analysis. Supply Chain Management: An International Journal, 10(1), 26-33. http://dx.doi.org/10.1108/13598540510578351

Lancastre, A., \& Lages, L. F. (2006). The relationship between buyer and a B2B e-marketplace: Cooperation determinants in an electronic market context. Industrial Marketing Management, 35(6), 774-789. http://dx.doi.org/10.1016/j.indmarman.2005.03.011

Lane, C., \& Bachmann, R. (1997). Co-operation in inter-firm relations in Britain and Germany: The role of social institutions. The British Journal of Sociology, 48(2), 226-254.

Lui, S. S., Ngo, H. Y., \& Hon, A. H. Y. (2006). Coercive strategy in inter firm cooperation: Mediating roles of interpersonal and inter-organizational trust. Journal of Business Research, 59(4), 466-474. http://dx.doi.org/10.1016/j.jbusres.2005.09.001

Lui, S. S., Wong, Y., \& Liu, W. (2009). Asset specificity role in inter firm cooperation: Reducing opportunistic behavior or increasing cooperative behavior? Journal of Business Research, 62(11), 1214-1219. http://dx.doi.org/10.1016/j.jbusres.2008.08.003

Mayer, R. C., Davis, J. H., \& Schoorman, F. D. (1995). An integrative model of organizational trust. Academy of Management Review, 20(3), 709-734. http://dx.doi.org/10.2307/258792

McAllister, D. J. (1995). Affect and cognition-based trust as foundations for interpersonal cooperation in organizations. Academy of Management Journal, 38(1), 24-59. http://dx.doi.org/10.2307/256727

McKnight, D. H., Cummings, L. L., \& Chervany, N. L. (1998). Initial trust formation in new organizational relationships. Academy of Management Review, 23(3), 473-490. http://dx.doi.org/10.5465/AMR.1998.926622

Miotti, L., \& Sachwald, F. (2003). Cooperative R\&D: Why and with whom? An integrated framework of analysis. Research Policy, 32(8), 1481-1499. http://dx.doi.org/10.1016/S0048-7333(02)00159-2

Morgan, R. M., \& Hunt, S. D. (1994). The commitment-trust theory of relationship marketing. Journal of Marketing, 58(3), 20-38. http://dx.doi.org/10.2307/1252308

Nguyen, N. P. (2011). Applying theory of reasoned action to explain inter-firm cooperation: Empirical evidence from Vietnamese enterprises. International Journal of Management \& Information Systems, 15(3), 61-81.

Nguyen, T. V., Weinstein, M., \& Meyer, A. D. (2005). Development of trust: A study of inter firm relationships in Vietnam. Asia Pacific Journal of Management, 22(3), 211-235. http://dx.doi.org/10.1007/s10490-005-3567-4

Nguyen, T. V., \& Rose, J. (2009). Building trust-evidence from Vietnamese entrepreneurs. Journal of Business Venturing, 24(2), 165-182. http://dx.doi.org/10.1016/j.jbusvent.2008.03.004

Nooteboom, B. (2002). Trust: Forms, foundations, functions, failures and figures. Edward Elgar Publishing Limited. UK. 
Pak, Y. S., Ra, W., \& Park, Y. R. (2009). Understanding IJV performance in a learning and conflict mediated context. International Business Review, 18(5), 470-480. http://dx.doi.org/10.1016/j.ibusrev.2009.07.006

Rodríguez, N. G., Pê, J. S., \& Gutiérrez, J. A. T. (2007). Inter-funtional trust as a determining factor of a new product performance. European Journal of Marketing, 41(5/6), 678-702. http://dx.doi.org/10.1108/03090560710737688

Rosenfeld, S. A. (1996). Does cooperation enhance competitiveness? Assessing the impacts of inter firm collaboration. Research Policy, 25(2), 247-263. http://dx.doi.org/10.1016/0048-7333(95)00835-7

Rotter, J. B. (1967). A new scale for the measurement of interpersonal trust. Journal of Personality, 35(4), 651-665. http://dx.doi.org/10.1111/j.1467-6494.1967.tb01454.x

Rousseau, D. M., Sitkin, S. B., Burt, R. S., \& Camerer, C. (1998). Introduction to special topic forum: Not so different after all: A cross-discipline view of trust. Academy of Management Review, 23(3), 393-404. http://dx.doi.org/10.5465/AMR.1998.926617

Sako, M. (1992). Price, quality and trust: Inter firm relations in Britain and Japan. Cambridge University Press.

Sako, M., \& Helper, S. (1998). Determinants of trust in supplier relations: Evidence from the automotive industry in Japan and the United States. Journal of Economic Behavior \& Organization, 34(3), 387-417. http://dx.doi.org/10.1016/S0167-2681(97)00082-6

Seppänen, R., Blomqvist, K., \& Sundqvist, S. (2007). Measuring inter-organizational trust- A critical review of the empirical research in 1990-2003. Industrial Marketing Management, 36(2), 249-265. http://dx.doi.org/10.1016/j.indmarman.2005.09.003

Shapiro, D. L., Sheppard, B. H., \& Cheraskin, L. (1992). Business on a handshake. Negotiation Journal, 8(4), 365-377. http://dx.doi.org/0.1111/j.1571-9979.1992.tb00679.x

Sitkin, S. B., \& Roth, N. L. (1993). Explaining the limited effectiveness of legalistic "remedies" for trust/distrust. Organizational Science, 4(3), 367-392. http://dx.doi.org/10.1287/orsc.4.3.367

Sztompka, P. (2003). Trust: A sociological theory. Cambridge University Press.

Wang, L., \& Gordon, P. (2011). Trust and institutions: A multilevel analysis. The Journal of Socio-Economics, 40(5), 583-593. http://dx.doi.org/10.1016/j.socec.2011.04.015

Wilson, J. M., Straus, S. G., \& McEvily, B. (2006). All in due time: The development of trust in computer mediated and face-to-face teams. Organizational Behavior and Human Decision Process, 99(1), 16-33. http://dx.doi.org/10.1016/j.obhdp.2005.08.001

Zaheer, A., McEvily, B., \& Perrone, V. (1998). Does trust matter? Exploring the effects of inter-organizational and interpersonal trust on performance. Organization Science, 9(2), 141-159. http://dx.doi.org/10.1287/orsc.9.2.141

Zaheer, S., \& Zaheer, A. (2006). Trust across borders. Journal of International Business Studies, 37(1), 21-29. http://dx.doi.org/10.1057/palgrave.jibs. 8400180

Zollo, M., Reuer, J. J., \& Singh, H. (2002). Inter-organizational routines and performance in strategic alliances. Organization Science, 13(6), 701-713. http://dx.doi.org//10.1287/orsc.13.6.701.503

Zucker, L. G. (1986). Production of trust: Institutional sources of economic structure, 1840-1920. In Staw, B. M., \& Cumming, L. L. (Eds.), Research in Organizational Behavior (pp. 53-111 ). Greenwich, CT: JAI Press. 